\title{
Lead Removal from Aqueous Solution Using Silica Ceramic: Adsorption Kinetics and Equilibrium Studies
}

\author{
Md. Salim (Corresponding author) \\ Environmental Engineering, Faculty of Agriculture \\ Kochi University \\ B200 Monobe, Nankoku, Kochi 783-8502, Japan \\ Bioresource Production Science \\ The United Graduate School of Agricultural Sciences \\ Ehime University, 3-5-7 Tarumi, Matsuyama, Ehime 790-8566, Japan \\ Tel: 81-88-864-5175 E-mail: mdsalim2@gmail.com \\ Yukihiro Munekage \\ Environmental Engineering, Faculty of Agriculture, Kochi University \\ B200 Monobe, Nankoku, Kochi 783-8502, Japan \\ Tel: 81-88-864-5175Ｅ-mail: munekage@kochi-u.ac.jp
}

\begin{abstract}
Kinetics adsorption of lead from aqueous solution using silica ceramic has been investigated in batch methods. The effect of solution $\mathrm{pH}$, initial metal ion concentration, temperature and adsorbent mass on metal ion removal has been studied. The process of lead adsorption follows pseudo second-order rate expression and obeys the Langmuir's model with high correlation coefficient $\left(\mathrm{R}^{2}>0.99\right)$ and better than other equations. The maximum removal achieves $2.7 \mathrm{mg} / \mathrm{g}$. The result indicates that under the optimum conditions, the maximum adsorption value for $\mathrm{Pb}$ (II) comply the silica ceramic is a potential adsorbent for $\mathrm{Pb}(\mathrm{II})$.
\end{abstract}

Keywords: Adsorption, Kinetic, Removal, Lead, Silica ceramic

\section{Introduction}

Industrial wastewaters are considered as the most important source of heavy metal pollutions among various heavy metals. Lead is a significant element metal that contaminated the water both natural and anthropogenic activities. Lead $(\mathrm{Pb})$ found in natural deposits and process include mineral breakdown, sedimentation of from dust storms, volcanic eruptions, forest fires etc. Anthropogenic activities of lead contamination including and smelting operations, commonly used in household plumbing materials and water service lines, metal plating, battery recycling, combustion of leaded gasoline, atomic energy installation, leatherworking, photography, salvages yards, urban and industrial waste, continuous of fertilizer, pesticides and use of $\mathrm{Pb}$ bullets (Sing et al., 2006; Heil et al., 1999) automobile, and oil industries produce more heavy metal ions that other industries (Reed and Arunachalam, 1994). It directly or indirectly causes damage or dysfunction to liver, reproductive system, brain and central nervous system, kidney and reduction in hemoglobin formation, mental retardation, infertility and abnormalities in pregnant women etc.

A variety of methods have been proposed for the treatment of wastewaters containing lead metals such as chemical precipitation (Matlock et al., 2001), electrochemical reduction, ion exchange (Inglezakis et al., 2007), membrane separation, flotation, biosorption (Nourbakhsh et al., 2002; Gupta and Ali, 2004) and adsorption (Mohan and Chander, 2006; Gupta and Sharma, 2002). Adsorption is being popular to be an economically viable alternative technique for removing lead from wastewater and water supplies. In recent years, there is an increase interest in using non-chemical and low-cost adsorbent (Salim et. al., 2007) to remove heavy metals from wastewater. The objective of the present study is to determine the functionality and sorption kinetics of silica ceramic as a low-cost adsorbent material to remove $\mathrm{Pb}$ (II) from aqueous phase. 


\section{Material and Method}

\subsection{Adsorbent}

Study used silica ceramic (powder particle size, $<0.05 \mathrm{~mm}$ ) obtained from EKOAIRANDO Co. Ltd. Kochi, Japan having major chemical ingredients $\mathrm{SiO}_{2}, \mathrm{Na}_{2} \mathrm{O}, \mathrm{Al}_{2} \mathrm{O}_{3}, \mathrm{CaO}$ and $\mathrm{K}_{2} \mathrm{O}$.

\subsection{Adsorbate}

The synthetic Stock solution of $\mathrm{Pb}$ (II) $(1000 \mathrm{mg} / \mathrm{L})$ was prepared using $\mathrm{Pb}\left(\mathrm{NO}_{3}\right)_{2}$ (Kanto Chemical Inc. Ltd., Japan) by dissolving in acidified ultra distilled water. The stock solution was diluted with distilled water to obtained desired concentration ranging from 5 to $70 \mathrm{mg} / \mathrm{L}$. Solutions of the $0.1 \mathrm{M} \mathrm{HCl}$ and $0.1 \mathrm{M} \mathrm{NaOH}$ were used for pH adjustment.

\subsection{Analytical method}

The surface area of the silica ceramic was measured by $\mathrm{N}_{2}$ adsorption using single point Brunauer, Element and Teller (BET) (Micrometric ASAP 2020, USA) procedure. The surface structure was examined by scanning electron microscopy (SEM-EDS, JEOL-JSM-6500F, Japan). Lead analysis was conducted by Atomic Absorption Spectrometer (AAnalyst200, Perkin-Elmer, Singapore) at a weave length of $283.31 \mathrm{~nm}$. All samples were analyzed after filtering within 24 hours of collection.

\subsection{Batch kinetics experiments}

Batch experiments were conducted for optimum dose, equilibrium time, effect of concentrations, and effects of temperature. Silica ceramic was added as per dose requirements to round bottom glass bottles of $100 \mathrm{ml}$ capacity with $50 \mathrm{ml}$ of $\mathrm{Pb}$ solutions of desire concentration $(10-50 \mathrm{mg} / \mathrm{L})$ and $(5.5-6.5) \mathrm{pH}$ range. The flasks were capped and placed on a mechanical shaker at a speed of $140 \mathrm{rpm}$ at $30{ }^{\circ} \mathrm{C}$, and samples were taken at predetermined intervals. All samples were filtered by a $0.45 \mu \mathrm{m}$ membrane filter and analyzed for $\mathrm{Pb}$. The amount of adsorbed $\mathrm{Pb}$ was calculated using Eq. (1) by the difference of initial and residuals amounts of $\mathrm{Pb}$ in solution divided by the mass of adsorbent. The removal efficiency, $R_{e}$, (determined as the $\mathrm{Pb}$ removal percentage relative to initial concentration) using Eq. (2) of the system, was calculated as:

$$
\begin{aligned}
& q_{e}=\frac{\left(C_{0}-C_{e}\right)}{M} \times V \\
& R_{e}=\frac{\left(C_{0}-C_{e}\right)}{C_{0}} \times 100
\end{aligned}
$$

Where, $\mathrm{q}_{\mathrm{e}}(\mathrm{mg} / \mathrm{g})$ is the amount of the $\mathrm{Pb}$ adsorbed per unit mass of silica ceramic. $\mathrm{C}_{0}$ and $\mathrm{C}_{\mathrm{e}}$ are the initial and equilibrium (or at any time) ion concentration $(\mathrm{mg} / \mathrm{L})$, respectively, $\mathrm{V}$ is the volume in liter of solution and $\mathrm{M}$ is the mass $(\mathrm{g})$ of the silica ceramic.

\subsection{Batch isotherms studies}

After determining the optimum $\mathrm{pH}$, temp and equilibrium time, isotherm studies were conducted by varying the mass of silica ceramic. Representative masses $(0.3,0.4,0.5 \ldots . .0 .9$ and $1.0 \mathrm{~g})$ of silica ceramic were add into $25 \mathrm{ml}$ of solution containing $10 \mathrm{mg} / \mathrm{L}$ of $\mathrm{Pb}$ ion for $3 \mathrm{~h}$, which is equilibrium time for the silica ceramic ion. The initial $\mathrm{pH}$ of the metal solutions was adjusted to an optimum value of 3.5 with $0.1 \mathrm{M} \mathrm{NaOH}$ or $\mathrm{HCl}$

\section{Results and Discussion}

\subsection{Adsorbent characterization}

The details physio-chemical properties are given in Table 1. The major components of chemical compositions of the silica ceramic are silicon, aluminum, sodium, calcium and potassium compounds. Both elemental and mineralogical characterization of silica ceramic verified its compositions. Scanning electron microscopy was performed on silica ceramic at different magnification to determine surface structure. The working tension was $15 \mathrm{KV}$. Scanning electron micrographs for intra structure of silica ceramic is shown in Figure 1 (A) and (B). The mineralogical analysis is shown in Figure 2. The figures indicate that silica ceramic has an extensive surface area, and it can be used as a potential adsorbent.

\subsection{Effect of $\mathrm{pH}$}

$\mathrm{pH}$ of solution is one of the most important parameters for adsorption of heavy metals from contaminated aqueous solution. Adsorption of $\mathrm{Pb}$ was studied at various $\mathrm{pH}$ and results are given away in Figure 3 . The initial $\mathrm{pH}$ of solution varied from 2.45 to 11.5 . In this experiments adsorbate concentration was $25 \mathrm{mg} / \mathrm{L}$, ceramic mass was $0.3 \mathrm{~g}$ to $1.0 \mathrm{~g}$ and contact time was $18 \mathrm{~h}$. From this figure it is clear that lead adsorption efficiency is high at bellow pH 4.5. This result showed similar trend to lead removal by zeolite and sepiolite (Turan et al., 2005); and by natural phosphate (Mouflih et. al., 2006). 


\section{3 kinetics study}

\subsubsection{Effect of concentration}

To evaluate the sorption characteristics of silica ceramic for lead ions, the change of sorption capacity with time for different initial solution concentrations has been investigated. A series of experiments were undertaken by varying the initial $\mathrm{Pb}$ concentration in the range $10-50 \mathrm{mg} / \mathrm{L}$ on removal kinetics of $\mathrm{Pb}$ from the solution. Figure 4 showed that adsorption of $\mathrm{Pb}$ (II) by silica ceramic increases as the initial $\mathrm{Pb}$ (III) concentration increased. The contact time required to reach the equilibrium of $\mathrm{Pb}(\mathrm{II})$ solution within $180 \mathrm{~min}$. However, the experimental data were measured at $600 \mathrm{~min}$ to confirm the complete equilibrium was reached.

\subsubsection{Adsorption Kinetics}

The adsorption kinetic data of lead are analyzed using three kinetics models were applied mainly, pseudo-first order, pseudo-second order and, intra-particle diffusion model rate equations.

Lagergren suggests the pseudo-first order kinetics rate equation (Lagergren, 1898), which is expressed as follows:

$$
\frac{d q_{t}}{d t}=k_{1}\left(q_{e}-q_{t}\right)
$$

Where $\mathrm{k}_{1}$ is the pseudo-first order rate constant, $\mathrm{q}_{\mathrm{e}}$ represents adsorption capacity. The integrating rate law by applying the initial condition of $\mathrm{t}=0$ to $\mathrm{t}$ and $\mathrm{q}_{\mathrm{t}}=0$ to $\mathrm{q}_{\mathrm{t}}$, Eq.(3) becomes:

$$
\log \left(\mathrm{q}_{\mathrm{e}}-\mathrm{q}_{\mathrm{t}}\right)=\log \mathrm{q}_{\mathrm{e}}-\left(\frac{\mathrm{k}_{1}}{2.303}\right) \mathrm{t}
$$

Where, $\mathrm{q}_{\mathrm{e}}$ and $\mathrm{q}_{\mathrm{t}}$ both $(\mathrm{mg} / \mathrm{g})$ are the amount of $\mathrm{Pb}(\mathrm{II})$ adsorbed per unit of mass of silica ceramic at equilibrium and time t. respectively, and $K_{1}$ the rate constant $(1 / \mathrm{min})$. The value for the $\mathrm{K}_{1}$ was calculated from the slope of the linear plot of $\log \left(\mathrm{q}_{\mathrm{e}}-\mathrm{q}_{\mathrm{t}}\right)$ versus $t$ [Figure 5. (a)]. The $\mathrm{K}_{1}$ values and correlation coefficients $\mathrm{R}^{2}$ are given in Table 2 .

The pseudo-second order reaction rate equation used by Ho et al (Ho et al., 1996) to study the kinetics of adsorption of heavy metals on peat. This model was also applied to assess the kinetics of adsorption of $\mathrm{Pb}$ (II) on silica ceramic. The equation is as follows:

$$
\frac{\mathrm{dq}_{\mathrm{t}}}{\mathrm{dt}}=\mathrm{k}_{2}\left(\mathrm{q}_{\mathrm{e}}^{2}-\mathrm{q}_{\mathrm{t}}\right)^{2}
$$

where $\mathrm{k}_{2}$ is the rate constant of pseudo second-order adsorption. The integrating rate law Eq.(5), after applying the initial conditions (McKay and Ho, 1999), and rearranging it gives as linearized form of pseudo second-order rate kinetics expressed as follows:

$$
\frac{\mathrm{t}}{\mathrm{q}_{\mathrm{t}}}=\frac{1}{\mathrm{k}_{2} \mathrm{q}_{\mathrm{e}}^{2}}+\frac{1}{\mathrm{q}_{\mathrm{e}}} \mathrm{t}
$$

In addition, initial rate of adsorption is $\mathrm{h}$ is:

$$
\mathrm{h}=\mathrm{k}_{2} \mathrm{q}_{\mathrm{e}}^{2}
$$

Where, $\mathrm{q}_{\mathrm{e}}$ and $\mathrm{q}_{\mathrm{t}}$ both $(\mathrm{mg} / \mathrm{g})$ are the amount of $\mathrm{Pb}(\mathrm{II})$ adsorbed per unit of mass of silica ceramic at equilibrium and time t. respectively, and $\mathrm{K}_{2}$ is the rate constant of pseudo second order adsorption $(\mathrm{g} / \mathrm{mg} \mathrm{min})$. The kinetics plots between $t / q_{t}$ versus $t$ were plotted for the different initial concentrations [Figure 5. (b)]. Slope and intercept values were solved to give the value of pseudo-second order rate constant (Table 2).

Figure 5 (b) and Table 2 shows that highly significant regression line $\left(\mathrm{R}^{2}>997\right)$ and the data were well fitted only to the pseudo second-order rate equation. The straight line was obtained indicating that the process follow a pseudo second order kinetics for various concentration of $\mathrm{Pb}(\mathrm{II})$. While the initial $\mathrm{Pb}(\mathrm{II})$ concentration increases from $10 \mathrm{mg} / \mathrm{L}$ to 50 $\mathrm{mg} / \mathrm{L}$, the adsorption capacity, $\mathrm{q}_{\text {exp }}$, increase from 0.9594 to $2.7048 \mathrm{mg} / \mathrm{g}$. This indicates that the initial $\mathrm{Pb}(\mathrm{II})$ concentration plays a key role in determining the adsorption capacity of $\mathrm{Pb}$ (II) on silica ceramic. It is also observed in Table 2 that when initial $\mathrm{Pb}(\mathrm{II})$ concentration increase from $10 \mathrm{mg} / \mathrm{L}$ to $50 \mathrm{mg} / \mathrm{L}$, the rate constant, $\mathrm{k}_{2}$ decrease from $277.397 \times 10^{-3}$ to $19.223 \times 10^{-3} \mathrm{~g} / \mathrm{mg}$ min and values of initial sorption rate $\mathrm{h}$ are also decrease from $258.853 \times 10^{-3}$ to $151.849 \times 10^{-3} \mathrm{mg} / \mathrm{g} \min$.

Lagergren pseudo first order and pseudo second-order rate equations cannot identify the diffusion mechanisms during the sorption process and uptake varies almost proportionately with the half-power of time, $\mathrm{t}^{1 / 2}$, rather than $\mathrm{t}$. A nearly linear variation in the quantity sorbed with $\mathrm{t}^{1 / 2}$ is predicted for a large initial fraction of reactions controlled by rates of 
intra-particle diffusion. Therefore, the experimental kinetic data were tested against intra-particle diffusion model. The initial rate of intra-particle diffusion can be determined by the most-widely applied intra-particle diffusion equation for sorption system is given by Weber and Morris (Weber and Morris, 1963):

$$
\mathrm{q}_{\mathrm{t}}=\mathrm{k}_{\mathrm{i}} \mathrm{t}^{1 / 2}+\mathrm{C}
$$

Where, $\mathrm{q}$ is the amount of $\mathrm{Pb}(\mathrm{II})$ adsorbed $(\mathrm{mg} / \mathrm{g})$ at time $\mathrm{t}, \mathrm{k}_{\mathrm{i}}$ the intra-particle diffusion constant $\left(\mathrm{mg} / \mathrm{g} \mathrm{min}^{1 / 2}\right)$, and C is the intercept.

The values of $\mathrm{k}_{\mathrm{i}}$ indicate an enhancement in the rate of adsorption. It is observed in Table 2 that when initial $\mathrm{Pb}$ (II) concentration increase from $10 \mathrm{mg} / \mathrm{L}$ to $50 \mathrm{mg} / \mathrm{L}$, the intra-particle diffusion constant, $\mathrm{C}$ and $\mathrm{k}_{\mathrm{i}}$ increase from 0.5316 to 0.9613 and from $27.1 \times 10^{-3}$ to $101.6 \times 10^{-3} \mathrm{~g} / \mathrm{mg}$ min respectively.

\subsubsection{Effect of temperature}

Effect of temperature on removal of $\mathrm{Pb}$ (II) were performed at three different temperatures, i.e., 20,30 , and $40^{\circ} \mathrm{C}$. The results are shown in Figure 6, which indicates that the $\mathrm{Pb}$ (II) uptake increases from 2.42 to 2.86 when temperature of the solution increases from 20 to $30^{\circ} \mathrm{C}$. After that, sorption uptake increase slowly from 2.86 to $2.90 \mathrm{mg} / \mathrm{g}$ when temperature of the solution increases 30 to $40^{\circ} \mathrm{C}$. The adsorption of lead on silica ceramic is highest at $40^{\circ} \mathrm{C}$. That means the sorption of $\mathrm{Pb}$ (II) is in favor of temperature indicates that the mobility of the lead molecule increases with an increase in the temperature. Therefore, it is revealed that the process is endothermic.

\subsubsection{Effect of adsorbent doses}

The effect of adsorbent dose was studied at a fixed initial concentration of $20 \mathrm{mg} / \mathrm{L}$ by silica ceramic mass varied from 5 to $40 \mathrm{~g} / \mathrm{L}$. The general trend indicates that 5 to $25 \mathrm{~g} / \mathrm{L}$ of sorbent dose uptake large amount of $\mathrm{Pb}(\mathrm{II})$, rapidly and 30 to $40 \mathrm{~g} / \mathrm{L}$ dose uptake little amount but slowly (Figure 7). At $10 \mathrm{~g} / \mathrm{L}$, removal efficiencies of $97.9 \%$ were observed and thereafter efficiency was $100 \%$ occurred slowly. The reason of removal efficiency increased due to the increase of adsorbent dose that means increase of the total available surface area of the adsorbent particles.

\subsection{Adsorption Isotherm}

The equilibrium adsorption isotherm is of importance in the design of adsorption systems (Wang et al., 2005). Several isotherm equations are available and the Langmuir isotherm is selected in this study. The Langmuir adsorption isotherms assumes that adsorption takes place at specific homogeneous sites within the adsorbent and has found successful application to many sorption process of monolayer adsorption. The Langmuir adsorption isotherm can be written as:

$$
\mathrm{q}_{\mathrm{e}}=\frac{\mathrm{q}_{\mathrm{m}} \mathrm{bC}_{\mathrm{e}}}{1+\mathrm{bC}_{\mathrm{e}}}
$$

The Langmuir parameters were obtained by fitting the experimental data to the linearized equation derived from Eq. (9):

$$
\begin{aligned}
& \frac{\mathrm{C}_{\mathrm{e}}}{\mathrm{q}_{\mathrm{e}}}=\frac{1}{\mathrm{bq}_{\mathrm{m}}}+\frac{\mathrm{C}_{\mathrm{e}}}{\mathrm{q}_{\mathrm{m}}} \\
& \frac{1}{\mathrm{q}_{\mathrm{e}}}=\frac{1}{\mathrm{bq}_{\mathrm{m}}} \frac{1}{\mathrm{C}_{\mathrm{e}}}+\frac{1}{\mathrm{q}_{\mathrm{m}}}
\end{aligned}
$$

Where, $\mathrm{q}_{\mathrm{e}}$ is the adsorbent amount (mg/g) of the $\mathrm{Pb}$ (II), $\mathrm{C}_{\mathrm{e}}$ is the equilibrium concentration of the $\mathrm{Pb}$ (II) in solution $(\mathrm{mg} / \mathrm{L}), \mathrm{q}_{\mathrm{m}}$ is the monolayer adsorption capacity $(\mathrm{mg} / \mathrm{g})$ and $\mathrm{b}$ is the constant related to the free energy of adsorption (L/mg).

Based on Eq. (10) and Eq. (11) the isotherms were fitted to the adsorption data obtained. The Langmuir adsorption exponents for Eq. (10) and Eq. (11), the $\mathrm{q}_{\mathrm{m}}$ and $\mathrm{b}$ are determined from the linear plots of $\mathrm{C}_{\mathrm{e}} / \mathrm{q}_{\mathrm{e}}$ versus $\mathrm{C}_{\mathrm{e}}$ (Figure not shown) and $1 / \mathrm{q}_{\mathrm{e}}$ versus $1 / \mathrm{C}_{\mathrm{e}}$ (Figure not shown) and calculated correlation coefficients for these isotherms, are shown in Table 3. The values of the Langmuir constant were calculated from the slopes and intercepts of the plots. The magnitude of Langmuir constant $\mathrm{b}$ is small $(1.8561 \mathrm{~L} / \mathrm{mg})$ and the adsorption capacity $\mathrm{q}_{\mathrm{m}}$ was determined as 2.7586 $\mathrm{mg} / \mathrm{g}$. In order to predict the adsorption efficiency of the adsorption process, the dimensionless equilibrium parameter $\mathrm{R}_{\mathrm{L}}$ was determined by using the following equation (Magdy and Daifullah, 1988):

$$
\mathrm{R}_{\mathrm{L}}=\frac{1}{\left(1+\mathrm{bC}_{0}\right)}
$$


Where, $\mathrm{C}_{0}$ is the initial concentration and $\mathrm{b}$ is the Langmuir isotherm constant. The parameter $\mathrm{R}_{\mathrm{L}}$ indicates the shape of isotherm. The process is irreversible if $R_{L}=0$, favorable if $R_{L}<1$, linear if $R_{L}=1$ and unfavorable if $R_{L}>1$. The Figure 9 shows that the $\mathrm{R}_{\mathrm{L}}$ values at different initial $\mathrm{Pb}$ (II) concentration indicating a highly favorable adsorption. As shown in Table 3 and Figure 8, the Langmuir equation represents adsorption process is very well and the correlation coefficient, $\mathrm{R}^{2}$ value is indicating a very good mathematical fit.

\section{Conclusions}

The results of present investigations revealed that silica ceramic is potential adsorbent to removal the $\mathrm{Pb}$ (II) from aqueous phase. The pseudo-second order kinetic models fits very well with the adsorption behavior of $\mathrm{Pb}$. The sorption suggested that the adsorption is high at low $\mathrm{pH}$ range. The amount of lead uptake at equilibrium increased with increasing solution concentrations, temperatures and decreasing $\mathrm{pH}$, sorbent mass. The findings of the study show that silica ceramic has excellent potential for use in the removal of $\mathrm{Pb}$ from waste water, however further work is increase the adsorption capacity of silica ceramic. Currently study is being progress involving the activation of silica ceramic by acid and heat treatment.

\section{Acknowledgements}

The authors wish to express their thanks to Asst. Prof. Le Thanh Son, Hanoi University of Science, Vietnam National University, Vietnam and Center for Advanced Marine Core Research, Kochi, Japan for chemical and mineralogical analysis of silica ceramic.

\section{References}

Gupta, V. K., \& Ali, I. (2004). Removal of lead and chromium from wastewater using bagasse fly ash- a sugar industry waste. $J$ Colloid Interf Sci, 271, 321-328.

Gupta, V. K., \& Sharma, S. (2002). Removal of cadmium and zinc from aqueous solution using red mud. Environ Sci Technol, 36(16), 3612-3617.

Heil, D. M., Samani, Z., Hanson, A. T., et al. (1999). Remediation of lead contaminated soils by EDTA. I. Batch and column studies. Water Air Soil Pollut, 13, 77-95.

Ho, Y. S., Wase, D. A. J., \& Forster, C. F. (1996). Kinetic studies of competitive heavy metal adsorption by sphagnum moss peat. Environ Technol, 17(1), 71-77.

Inglezakis, V. J., Stylianou, M. A., Gkantzou, D., et al. (2007). Removal of Pb(II) from aqueous solutions by using clinoptilolite and bentonite as adsorbents. Desalination, 210, 248-256.

Lagergren, S. (1898). Zur theorie der sogenannten adsorption geloster stoffe. Kungliga Svenska Vetenskapsakademiens. Handl, 24(4), 1-39.

Magdy, Y. H., \& Daifullah, A. A. M. (1988). Adsorption of a basic dye from aqueous solutions onto sugar-industry-mud in two modes of operations. Waste Manage, 18 (4), 219-226.

Matlock, M. M., Howerton, B. S., \& Atwood, D. A. (2001). Irreversible precipitation of mercury and lead. J Hazard Mater, 84, 72-83.

Mckay, G., \& Ho, Y. S. (1999). Pseudo-second-order model for sorption processes. Process Biochem., 34, 451-465.

Mohan, D., \& Chander, S. (2006). Removal and recovery of metal ions from acid mine drainage using lignite-a low cost sorbent. J Hazard Mater, B137, 1545-1553.

Mouflih, M., Akil, A., Jahroud, N., et al. (2006). Removal of lead from aqueous solution by natural phosphate. Hydrometallurgy, 81, 219-225.

Nourbakhsh, M. N., Kiliçarslan, S., Ilhan, S., et al. (2002). Biosorption of $\mathrm{Cr}^{+6}, \mathrm{~Pb}^{+2}$ and $\mathrm{Cu}^{+2}$ ions in industrial waste water on Bacillus sp. Chem Eng J, 85, 351-355.

Reed, B. E., \& Arunachalam, S. (1994). Use of granular activated carbon columns for lead removal. J Environ Eng, ASCE, 120, 416- 436.

Salim, M., Munekage, Y., \& Naing, K. M. (2007). Arsenic removal from contaminated water using silica ceramic: A batch adsorption study. J app. Sci. 7(16), 2314-2320.

Sing, S. P., Ma, L. Q., \& Hendry, M. J. (2006). Characterization of aqueous lead removal by phosphatic clay: Equilibrium and Kinetic studies. J Hazard Mater, B136, 654-662.

Turan, M., Mart, U., Yuksel, B., et al. (2005). Lead removal in fixed-bed columns by zeolite and sepiolite. Chemosphere, 60(10), 1487-1492. 
Wang, S., Boyjoo, Y., \& Choueib, A. (2005). A Comparative study of dye removal using fly ash treated by different methods. Chemosphere, 60(10), 1401-1407.

Weber, W. J., \& Morris, J. C. (1963). Kinetics of adsorption on carbon from solution. J Sanit Eng Div ASCE, 89 (SA2), $31-59$.

Table 1. Physical and chemical properties of absorbent used in the experiments

\begin{tabular}{llll}
\hline Chemical properties & wt. \% & Physical properties & Value \\
\hline $\mathrm{SiO}_{2}$, & 80.81 & Surface area $(\mathrm{BET}),\left(\mathrm{m}^{2} / \mathrm{g}\right)$ & 340.38 \\
$\mathrm{CaO}$ & 6.93 & Median Pore diameter $(\mathrm{A})$ & 44.46 \\
$\mathrm{Al}_{2} \mathrm{O}_{3}$ & 3.80 & Pore Volume $\left(\mathrm{cm}^{3} / \mathrm{g}\right)$ & 0.3274 \\
$\mathrm{Na}_{2} \mathrm{O}$ & 2.57 & $\mathrm{pH}(1 \%$ Solution $)$ & 8.5 \\
$\mathrm{~K}_{2} \mathrm{O}$ & 1.84 & Particle size, $\mathrm{mm}$ & $<0.05$ \\
\hline
\end{tabular}

Table 2. Lagergren constants, Pseudo second-order rate constants and Intra-particle diffusion constants for lead adsorption on silica ceramic at different initial concentration

\begin{tabular}{|c|c|c|c|c|c|c|c|c|c|}
\hline \multirow{2}{*}{$\begin{array}{l}\mathrm{Pb} \\
(\mathrm{mg} / \mathrm{L})\end{array}$} & \multirow[b]{2}{*}{$q_{\exp }$} & \multicolumn{2}{|c|}{ Lagergren constants } & \multicolumn{4}{|c|}{ Pseudo second-order rate constants } & \multicolumn{2}{|c|}{ Intra-particle diffusion } \\
\hline & & $K_{1} \times 10^{-3}$ & $\mathrm{R}^{2}$ & $\overline{q_{e}}$ & $K_{2} \times 10^{-3}$ & $h \times 10^{-3}$ & $\mathrm{R}^{2}$ & $\bar{C}$ & $K_{i} \times 10^{-3}$ \\
\hline 10 & 0.9594 & 34.775 & 0.7244 & 0.966 & 277.397 & 258.853 & 1 & 0.5316 & 27.1 \\
\hline 20 & 1.8718 & 33.624 & 0.9455 & 1.912 & 44.380 & 162.248 & 0.9999 & 0.8416 & 60.4 \\
\hline 30 & 2.5088 & 22.569 & 0.9176 & 2.6596 & 11.064 & 78.260 & 0.999 & 0.6858 & 97.5 \\
\hline 40 & 2.6264 & 31.781 & 0.9421 & 2.7563 & 14.957 & 113.636 & 0.9981 & 0.8395 & 100.9 \\
\hline 50 & 2.7048 & 32.703 & 0.8939 & 2.8106 & 19.223 & 151.849 & 0.9977 & 0.9613 & 101.6 \\
\hline
\end{tabular}

Table 3. Langmuir isotherm constant for adsorption of $\mathrm{Pb}(\mathrm{II})$ by silica ceramic

\begin{tabular}{lll}
\hline Langmuir isotherm parameters & $\mathrm{C}_{\mathrm{e}} / \mathrm{q}_{\mathrm{e}}$ & $1 / \mathrm{q}_{\mathrm{e}}$ \\
\hline $\mathrm{q}_{\mathrm{m}}(\mathrm{mg} / \mathrm{g})$ & 2.7586 & 2.7586 \\
$\mathrm{~b}(\mathrm{~L} / \mathrm{mg})$ & 1.8561 & 1.8561 \\
$\mathrm{R}^{2}$ & 0.9999 & 1 \\
\hline
\end{tabular}
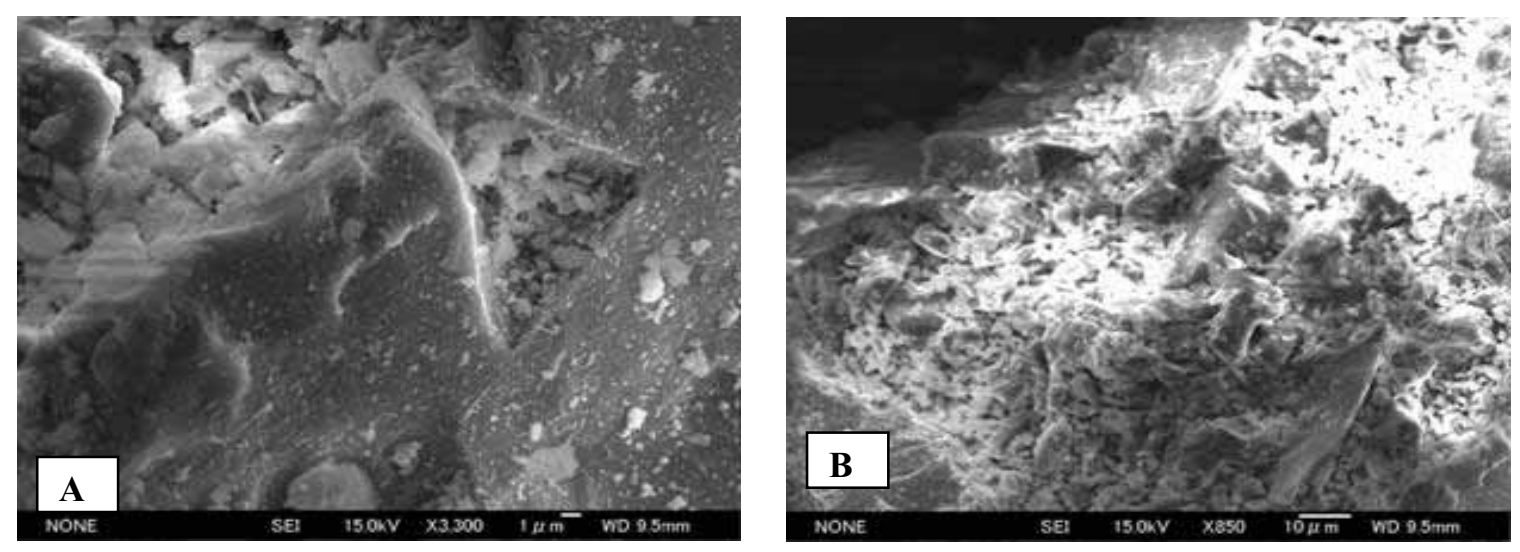

Figure 1 . SEM of silica ceramic: $(A) \times 3300,1 \mu \mathrm{m}$; $(\mathrm{B}) \times 850,10 \mu \mathrm{m}$ 


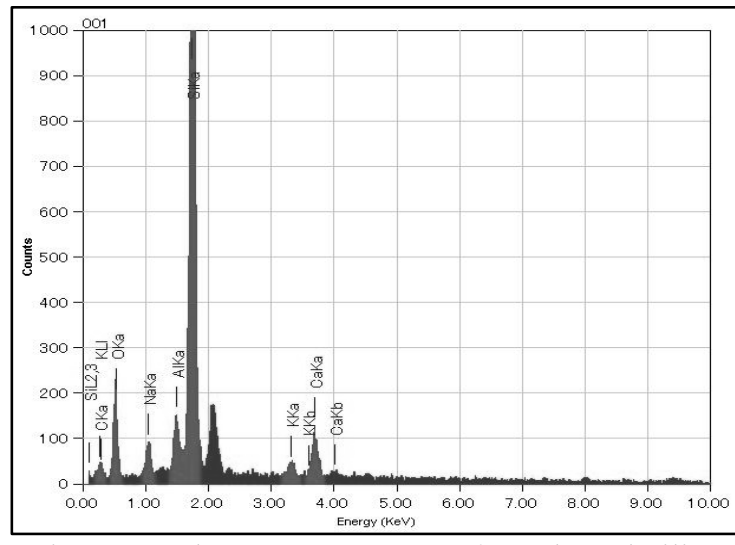

Figure 2. Elements spectrum of a selected silica ceramic obtained by SEM-EDS analysis

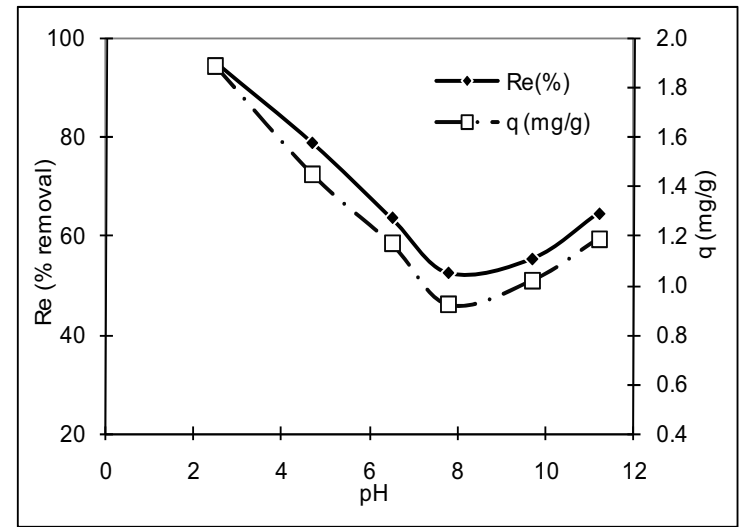

Figure 3. Effect of $\mathrm{pH}$ on adsorption of $\mathrm{Pb}(\mathrm{II})$ by silica ceramic at temperature $25^{\circ} \mathrm{C}$

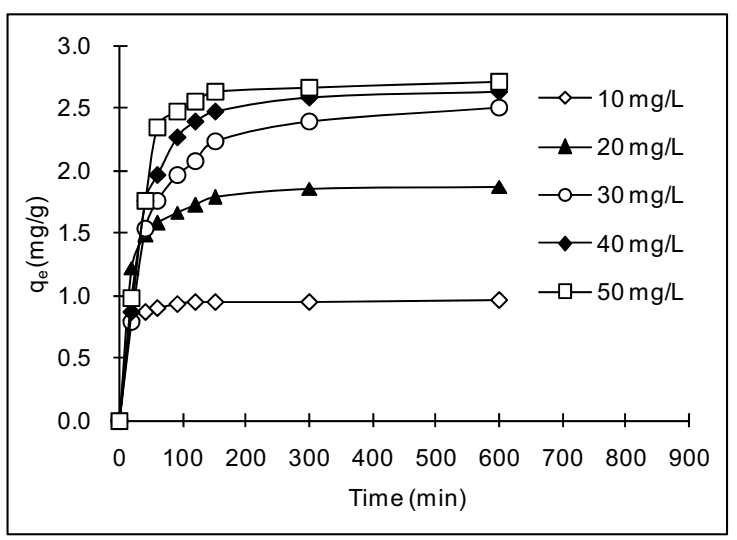

Figure 4. Effect of initial concentration on $\mathrm{Pb}(\mathrm{II})$ adsorption by silica ceramic at $\mathrm{pH} 5.5$
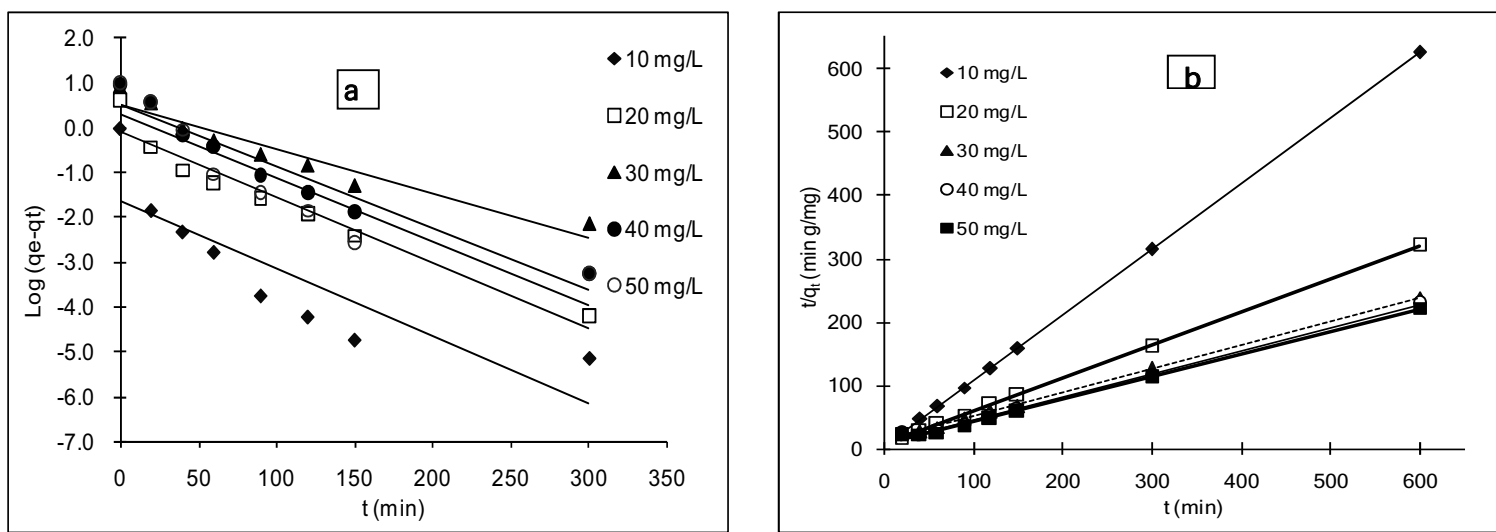

Figure 5. Kinetics analysis of pb(II) adsorption by linear plots of (a) pseudo first-order, (b) pseudo second-order rate equations 


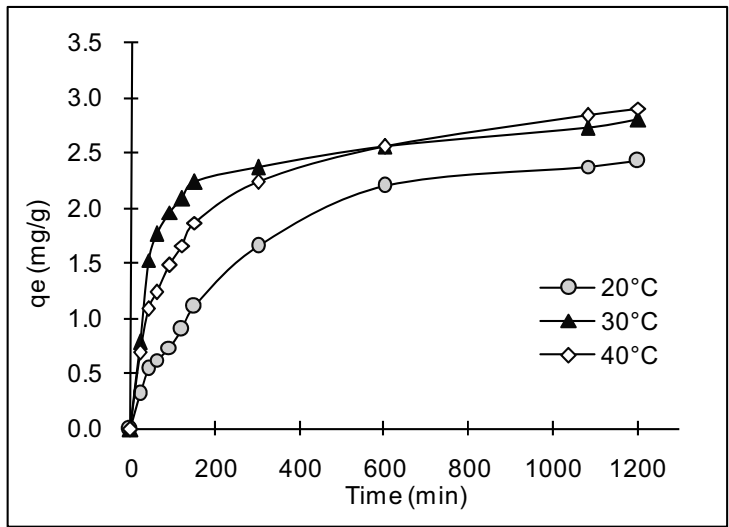

Figure 6. Effect of temperature on $\mathrm{Pb}(\mathrm{II})$ adsorption

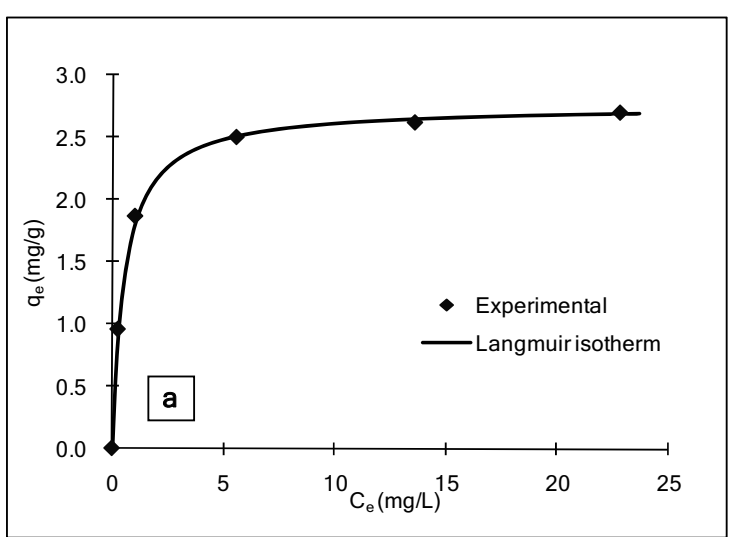

Figure 8. Langmuir adsorption isotherm of $\mathrm{Pb}(\mathrm{II})$ on silica ceramic

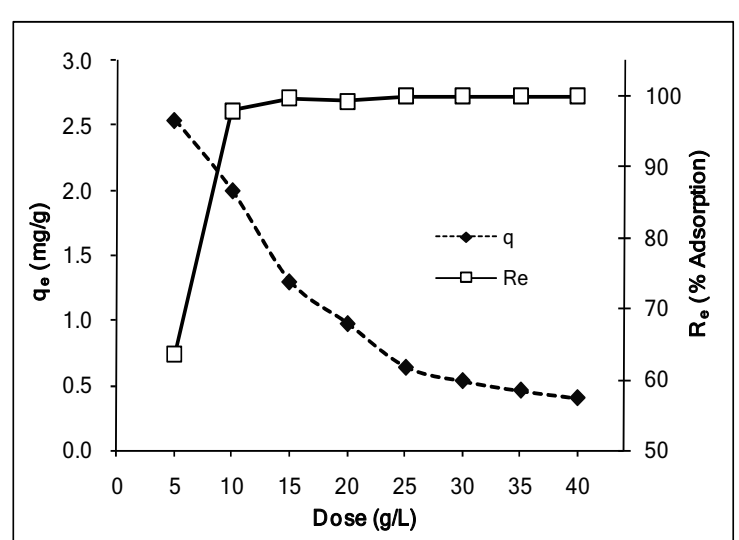

Figure 7. Effect of adsorbent dose on $\mathrm{Pb}(\mathrm{II})$ adsorption.

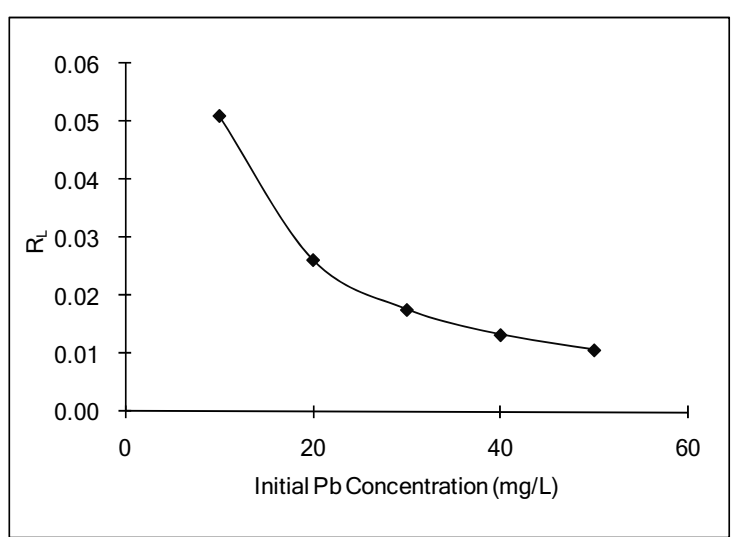

Figure 9. Separation factor for $\mathrm{Pb}(\mathrm{II})$ adsorption using silica ceramic 